\title{
The Influence of PACE Learning Model on Mathematical Problem-Solving Ability
}

\author{
$1^{\text {st }}$ Siti Ambarwati \\ Mathematics Department \\ Universitas Negeri Padang \\ Padang, Indonesia \\ siti_ambarwati77@yahoo.co.id
}

\author{
$2^{\text {nd }}$ Ahmad Fauzan \\ Mathematics Department \\ Universitas Negeri Padang \\ Padang, Indonesia \\ fauzan_math@fmipa.unp.ac.id
}

\author{
$3^{\text {rd }}$ Ahmad Fauzi \\ Physics Department \\ Universitas Negeri Padang \\ Padang, Indonesia
}

\begin{abstract}
The aims of this research to determine effect of PACE learning model on mathematical problem-solving ability. The research method used is quasi experiment. The research's subject was 64 students at grade 8 SMPN 1 Pariaman, Indonesia. Data were collected through problem solving test and then analyzed by using t-test. The results showed that the mathematical problem-solving ability in the experimental class better than the control class. It can be concluded that the PACE model contributed to the improvement of mathematical problem-solving ability
\end{abstract}

Keywords - Mathematical Problem-Solving Ability, Learning Mathematics, PACE Model

\section{INTRODUCTION}

Mathematical problem-solving is one of important parts that must be developed in learning mathematics. Mathematical problem-solving can be used as a vehicle in searching for a war out of a mathematical difficulty [1]. The National Council of Teachers of Mathematics (NCTM) mentioned that in learning mathematics, students must have problem-solving abilities, reasoning and evidence, communication, connection, and representation [2]. Similar matters are mentioned in Permendikbud Number 21 of 2016 on Basic and Secondary Education Content Standards that the learning of mathematics aims to students had the skills mathematics as part of life skills that should be owned by students, especially in the development of reasoning, communication, and problem-solving encountered in everyday life [3]. Ersoy (2016) also suggested that it is important for students to have mathematical problemsolving ability as it will help them to solve various forms of mathematical problems [4]. In addition, other researchers (see Branca, 1980; Nurmarisa, et, al, 2016; Rostika and Junita, 2017) suggested the importance of mathematical problem-solving in learning mathematics $[5,6,7]$.

The purpose of mathematics learning in the curriculum of Indonesia is one of the ability to develop students' mathematical problem-solving. But the reality that occurred in the field shows that students' mathematical problemsolving ability is still not developed optimally. One cause of this problem is presumably because of the way of managing learning that still has not provided many opportunities for students to develop mathematical problem-solving skills because students tend not to get used to construct their knowledge through practice questions. The cause of low mathematical ability of students are the wrong perception of teachers who consider that group learning takes a long time and often occur in the commotion of learning [1]. As a result, the knowledge obtained by students is less meaningful and easily forgotten.

Based on the problems that have been described, then to develop mathematical problem-solving ability is required serious efforts by teachers in managing the learning process by providing opportunities for students to actively engage in material review and can construct knowledge by own ability through activities such as familiarize students to work on math problems that involve high-order thinking skills in order to train problem-solving skills of students. The learning given to students in practicing the mathematical problems-solving ability always associated with real life students [7]. States that learning with lots of practice to solve problems will make students skilled in solving math problems [8].

One of the learning models that is believed to be very potential to develop problem solving abilities of mathematics is the PACE learning model. The PACE learning model was developed by Carl Lee since 1998 which stands for Project, Activity, Cooperative Learning, and Exercise. Students applying the PACE model in their learning will be much more involved in active learning through group work and class discussions [9]. The PACE learning model is good to be applied in mathematics learning because it can cultivate creative thinking act mathematically [10].

Conventional learning follows how learning is usually carried out and in general lessons are implemented applying scientific learning. Scientific learning is a learning activity involving observation or observation activities [11]. Scientific learning is a learning process designed in such a way that students actively construct concept, laws or principles through stages of observing, formulating hypotheses, collecting data with various techniques, analyzing data, drawing conclusions and communicating concepts [12]. Stages in scientific learning include activity activities observing, asking, processing, presenting data, and communicate it [13].

Learning of mathematics by applying PACE learning model emphasizes on the active involvement of students in learning and provides opportunities for students to be able to exchange ideas with peers through group learning and provide opportunities for students to develop the mind through the concepts found by doing the problem exercises. Project is a form of learning that emphasizes the problemsolving ability [14]. Then, a learning that involves activity students can also develop problem-solving skills. Activity in 
PACE model aims to introduce students to information or new concepts to be able to better understand the learning materials through exercise questions [14].

Furthermore, through Cooperative learning students the opportunity to express the findings obtained at the time of discussion because during the discussion of exchanging information that complement each other so that students have a correct understanding of a concept. Exercise in the PACE model aims to reinforce concepts that have been constructed at the stage of activity and cooperative learning [14]. The PACE learning model is important in mathematics learning, as it can make students much more involved in active learning through group work and can discover new concepts through assigned tasks and get an opportunity to connect the material learned in real life. Overall, learning the PACE model will make learning mathematics more fun and meaningful.

From the description above, researchers want to know the extent of the influence of the application of PACE learning model for students' mathematical problem-solving abilities. Therefore, the researcher is interested in raising the title "The Influence of PACE Learning Model on Mathematical Problem-Solving Ability". The subject of this research is focused on the statistical materials and opportunities that are being studied by the $8^{\text {th }}$ grade of SMPN 1 Pariaman in the even semester of the academic year 2017/2018.

\section{METHODS}

The population of this study is the students at grade 8 SMP Negeri 1 Pariaman registered in the school year 2017/2018 consisting of 6 classes and amounted to 189 students. Sampling is done randomly, selected as experimental class is 8.6 with 31 students and 8.3 as control class with 31 students.

This type of research is experimental quasi because the selected sample groups are already in group from, no need to be grouped again. The study design was randomized group only design. Research design can be seen on table I.

TABLE I. RESEARCH DESIGN

\begin{tabular}{|l|c|c|}
\hline \multicolumn{1}{|c|}{ Class } & Treatment & Test \\
\hline Experimental & $\mathrm{X}$ & $\mathrm{T}$ \\
\hline Control & - & $\mathrm{T}$ \\
\hline \multicolumn{2}{|c|}{ Note: $\mathrm{X}$ (Treatment with PACE Model), T (Test) } \\
\hline \multicolumn{2}{|c}{}
\end{tabular}

Table I indicates that the treatment given in the experimental class, the researchers applied the PACE model in the learning. While in the control class, researchers did not apply the PACE model in learning but applied scientific learning. The sample is obtained randomly by using the lottery. The independent variable in this research is learning applying PACE model. Meanwhile, the dependent variable is the students' mathematical problem-solving abilities.

Initial analysis was conducted to test whether the application of PACE learning model has an effect on mathematical problem-solving ability of $8^{\text {th }}$ grade students of SMPN 1 Pariaman using t-test. Furthermore, further test is done to see the difference of mathematical problem-solving ability of students applying PACE model in learning and mathematical problem-solving ability of students who do not apply PACE model in learning by using statistical value description.

\section{RESULTS AND DISCUSSION}

Difference in mathematical problem-solving ability of students applying PACE learning model in learning with mathematical problem-solving ability of students who do not apply PACE learning model in learning done by t-test, as can be seen on Table II.

TABLE II. The DifFERENCES StUdents' MATHEMATICAL PROBLEMSOLVING ABILITY ON EXPERIMENTAL AND COTROL ClASSES

\begin{tabular}{|l|r|l|r|}
\hline \multicolumn{2}{|c|}{ Experimental Class } & \multicolumn{2}{c|}{ Control Class } \\
\hline Mean & 75.2 & Mean & 70.3 \\
\hline Median & 75 & Median & 70 \\
\hline Mode & 75 & Mode & 70 \\
\hline Rtandard Deviation & 5.43 & Standard Deviation & 8.13 \\
\hline Minimum & 25 & Range & 28 \\
\hline Maximum & 65 & Minimum & 60 \\
\hline Sum & 90 & Maximum & 2180 \\
\hline Count & 3332 & Sum & Count \\
\hline
\end{tabular}

Note: Experimental Class (Applied PACE Model), Control Class (Applied Scientific Learning)

From the Table II it can be seen that the mean value of mathematical problem-solving ability of students applying PACE model in learning is 75.2 whereas the mean value of mathematical problem-solving ability of students who do not apply PACE model in their learning is 70.3 . It can be said that the mean value of these two samples is different and it is clear that the average score of students applying the PACE model in learning is greater than the mean score of students who do not apply the PACE model. With the standards deviation of students applying PACE model in learning is 5.43 while the standard deviation of students who do not apply PACE model is 8.13. To see differences in students' mathematical problem-solving abilities in applying PACE model in learning and mathematical problem-solving ability of students who do not apply PACE model in learning using statistical value descriptions. For the further can be seen on table III.

TABLE III. THE FURTHER COMPARISON OF STUDENTS' MATHEMATICAL PROBLEM-SOLVING ABILITY ON EXPERIMENTAL AND Cotrol Classes

\begin{tabular}{|l|c|c|c|}
\hline Class & Experimental & Control & Total \\
\hline High & 20 & 16 & 36 \\
\hline Low & $62.50 \%$ & $50.00 \%$ & $56.25 \%$ \\
\hline Total & 12 & 16 & 28 \\
& $37.50 \%$ & $50.00 \%$ & $43.75 \%$ \\
\hline
\end{tabular}

Note: Experimental (Applied PACE Model), Control (Applied Scientific Learning) 
From the Table III it can be seen that as many as 20 students or $62.50 \%$ of the number of students who participate in learning by applying the PACE model has the ability to solve mathematical problems greater than or equal to the mean score compared to students who follow the lesson without applying the model PACE with the number of 16 students or $50.00 \%$. The table III describes students' mathematical problem-solving abilities that apply the PACE model and do not apply the PACE model in learning that is greater than or equal to the mean score is $62.50 \%$ and $50.00 \%$. While the students' mathematical problem-solving abilities apply the PACE model and do not apply the PACE model in lesser learning than mean score is $37.50 \%$ and $50.00 \%$.

\section{CONCLUSIONS}

Based on the results of research conducted on classes 8.3 and 8.6 SMPN 1 Pariaman can be concluded that students' mathematical problem-solving ability with apply PACE model in learning is better than students' mathematical problem-solving ability with do not apply PACE model in learning. This can be proved by the mean obtained by the students. The mean of students' mathematical problemsolving with apply PACE model learning is 75.2 whereas the mean of students' mathematical problem-solving with do not apply PACE model learning is 70.3 .

Thus, it is evident that the mathematical problem-solving ability of students in the learning applying PACE model is better than the problem-solving ability mathematical students whose learning does not apply the model of PACE.

\section{REFERENCES}

11] W. Susanti, et al, "Improvement of Students Mathematics ProblemSolving Abilities Through the LAPS-Heuristic Learning Model in Class X SMAN 2 Batang Anai," Journal of GANTANG Mathematics Education FKIP-UMRAH, vol. 1, no. 2, p-ISSN. 2503-0671, e-ISSN. 2548-5547, 2016

[2] NCTM. Principles and Standards for School Mathematics. NCTM: USA, 2000

[3] BSNP. Permendikbud RI No. 21 of 2016 on Content Standard for Basic and Secondary Education Units. Jakarta: Ministry of Education and Culture, 2016.

[4] E. Ersoy, "Problem Solving and Its Teaching in Mathematics," The Online Journal of New Horizons in Education, vol. 6, no. 2, pp. 7987.

[5] N.A. Branca., Problem Solving is a Goal, Proces and Basic Skill. In S. Krulik and R.E. Reys (Ed.), Problem Solving in School Mathematics. Virginia: NCTM Inc, 1980.

[6] N.I. Nurmarisa, et al, "Mathematical Problem Solving Ability Students Get Learning with Mathematical Habits of Minds Based Problem Strategy,” UPI Antalogy, 2011.

[7] D. Rostika and H. Junita, "Improvement of Problem Solving Ability of Elementary Students in Mathematics Learning with Model Diskursus Multy Representation (PMR)," EduHumaniora: Journal of Elementary Education, vol. 9, no. 1, ISSN 2085-1234.

[8] H.W. Riski, "Mathematics Learning Experiment with Team Assited Individualization and Quiz Team Strategies in Term of Problem Solving Ability Class VIII Students in SMP Muhammadiyah 8 Surakarta," Proseedings of the National Seminar on Mathematics Education, ISSN: 2528-4630, 2017.

[9] L. Carl. An Assessment of the PACE Strategy for an Introduction Statistic Course. USA: Central Michigan University, 1998.

[10] S.W. Indah, "Growing Creative Thinking Through PACE Learning Model," Journal of Mathematics Education and Learning (JP2M), vol. 1, no. 1, ISSN: 2460-7800.

[11] R.A. Sani. Scientific Learning for Curriculum Implementation 2013. Jakarta: PT Bumi Aksara, 2014
[12] Sufairoh, "Scientific Approach \& K-13 Learning Model," Journal of Professional Education, vol. 5, no. 3, pp. 120-121, 2016.

[13] Rusindrayanti and H. Rusgianto, "Implementation of Classical Math Approach Mapel Mathematics Class VII Lesson Year 2013/2014 on Curriculum 2013 DIY," PYTHAGORAS Journal of Mathematics Education, vol. 10, no. 1, pp. 80-94, 2015.

[14] A. Suryana, "Improving Mathematical Representation Skill by Using PACE Model," Proceeding of International Conference on Research, Implementation and Education of Mathematics and Science Yogyakarta State University, ISBN: 978-979-99314-8-1, 2014. 